\title{
A Statistical Study of Growth and Maintenance in the Plaice (Pleuronectes platessa L.).
}

\author{
By
}

Ben Dawes, A.R.C.S., D.I.C., F.L.S.

With 5 Figures in the Text.

CONTENTS.

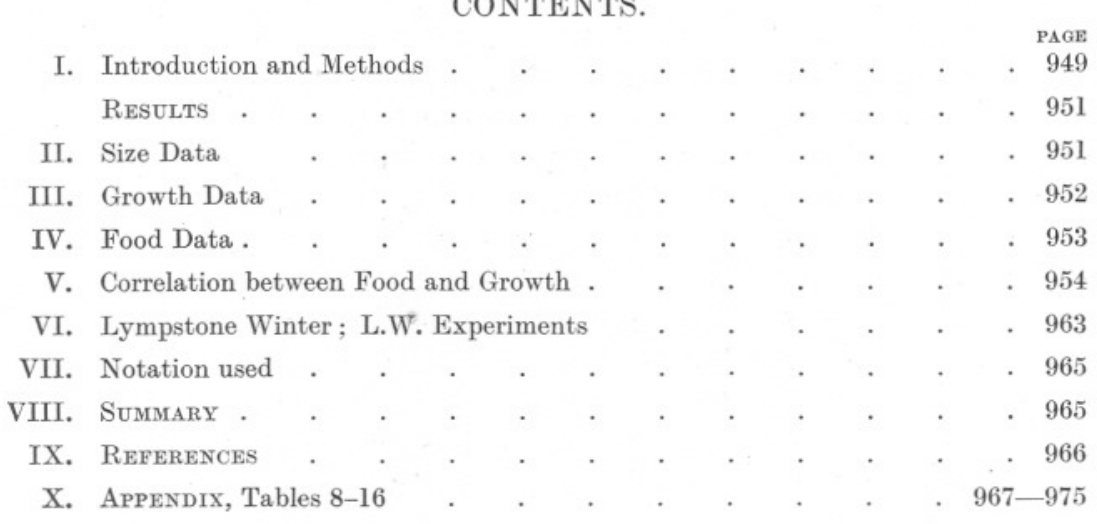

I. Introduction and Methods.

THE data for this paper were obtained from experiments carried out at Cawsand and Lympstone under the auspices of the Marine Biological Association during the years 1929-30 and subject to the direction of Dr. E. J. Allen, F.R.S. The aim of the experiments was to determine the maintenance requirements and growth efficiency of plaice during the third season of growth, and to ascertain what fraction of total food taken by such fish is available for growth promotion. To some extent this aim has already been realised, for in two previous papers ( 1 and 2 ) many data have been presented and discussed and interesting conclusions bearing upon growth and maintenance have been put forward. To these papers the reader is referred also for a full description of the experimental methods employed and the practical difficulties encountered. In one important respect, however, the results of the work remain incompletely expressed due to the purely arithmetic mode of treatment of the data, which remain in rather unwieldy form and show a heterogeneity entirely due to variable 
performances. In the first instance it was essential to emphasise this variability, but ultimately the indices of growth efficiency and maintenance must relate to populations rather than to individuals if they are to be of maximum assistance to fishery research. The aim of the present paper is to remedy this deficiency by applying appropriate statistical treatment to the data, thus enabling them to be presented in more compact and more satisfactory form. At the outset it is desired to thank Mr. T. Edser of the " $\mathrm{S}$ " Branch of the Ministry of Agriculture and Fisheries for his suggestion that the work be undertaken and for invaluable assistance willingly rendered.

A glance at my previous papers will serve to show that the experiments were divided up into periods of approximately a fortnight in duration, so that each period may be regarded as a separate experiment yielding definite results. In the present paper, it is intended to consider these periods as units, after reducing by simple proportion where necessary to periods of 14 days. Larger masses of data are thereby rendered available and can be dealt with statistically; the individual is the plaice used in one unit period of 14 days. Weight increase (to be expressed in grammes) and food taken (to be expressed as a percentage of the initial body-weight) are the only growth characteristics utilised, and factors such as temperature are of necessity ignored, except in as far as the mean temperature differs from one place to another and from one year to the next. The aim of the work may be more closely defined as being to determine the maintenance requirements and growth efficiency of the average member of $a$ plaice community during the "average" fortnight of the third season of growth.

In setting out the data initially, weight changes were considered to the nearest $0 \cdot 1 \mathrm{gm}$., food quantities to the nearest 1 per cent, but in compiling the tables, grouping was effected into $1.0 \mathrm{gm}$. and in 10 per cent classes, except in the case of the L.W. experiments, where $1.0 \mathrm{gm}$. and 5 per cent classes were formed. Males and females were considered separately in order to ascertain the possibility of marked differences in degree of correlation or in steepness of the regression lines, and Cawsand and Lympstone results were kept separate for similar reasons. All calculations have been made by the use of four-figure logarithms, have been carried out twice independently, and then finally checked. In my previous papers many scraps of data were omitted for the sake of brevity since they did not materially affect conclusions formed, but in the present paper all available data have received due consideration. It is usual in work of this kind to reject extreme variates following upon the use of Chauvenet's criterion and prior to calculation of statistical characteristics, but in this case suspected extreme variates are relatively numerous and it was deemed advisable to let them stand. 


\section{RESULTS.}

\section{Size Data.}

The primary consideration of defining as closely as possible the size limits of and the distribution of sizes in the various statistical populations is made in Table 1, where relevant summarised size data are shown.

TABLE 1.

Summarised Body-Weight Data Defining the Statistical Populations.

\begin{tabular}{|c|c|c|c|c|c|c|c|c|c|}
\hline Population. & Sex. & $\begin{array}{c}\text { No. } \\
\text { of } \\
\text { Fish. }\end{array}$ & $\begin{array}{l}\text { Lower. } \\
\text { Limit }\end{array}$ & $\begin{array}{c}\text { Lower } \\
\text { Quartile } \\
\text { Q1. }\end{array}$ & $\begin{array}{c}\text { Median } \\
\text { Q2. }\end{array}$ & $\begin{array}{c}\text { Upper } \\
\text { Quartile } \\
\text { Q3. }\end{array}$ & $\begin{array}{l}\text { Upper } \\
\text { Limit. }\end{array}$ & $x_{ \pm} \overline{\frac{\sigma_{x}}{\sqrt{n}}}$ & $\pm \sigma_{\mathrm{x}}+\frac{\sigma_{\mathrm{x}}}{\sqrt{2 \mathrm{n}}}$ \\
\hline C1929 & $\hat{\sigma}$ & 175 & 13 & $21 \cdot 7$ & $29 \cdot 9$ & $43 \cdot 2$ & 105 & $35 \cdot 2 \pm 1 \cdot 3$ & $18 \cdot 0 \pm 1 \cdot 0$ \\
\hline & 우 & 189 & 15 & $27 \cdot 0$ & $38 \cdot 6$ & $57 \cdot 2$ & 105 & $44 \cdot 6 \pm 1 \cdot 6$ & $22 \cdot 0 \pm 1 \cdot 1$ \\
\hline C 1930 & $\widehat{\delta}$ & 181 & 18 & $33 \cdot 9$ & $46 \cdot 4$ & $64 \cdot 0$ & 118 & $52 \cdot 7 \pm 1 \cdot 8$ & $24 \cdot 2 \pm 1 \cdot 3$ \\
\hline & 우 & 194 & 17 & $32 \cdot 5$ & $47 \cdot 3$ & $61 \cdot 6$ & 141 & $54 \cdot 1 \pm 2 \cdot 1$ & $29 \cdot 5 \pm 1 \cdot 5$ \\
\hline L 1929 & $\delta$ & 117 & 21 & $57 \cdot 7$ & $79 \cdot 0$ & $109 \cdot 8$ & 159 & $84 \cdot 0 \pm 3 \cdot 0$ & $32 \cdot 1 \pm 2 \cdot 1$ \\
\hline & 우 & 111 & 27 & $61 \cdot 1$ & $74 \cdot 2$ & $112 \cdot 7$ & 186 & $90 \cdot 4 \pm 4 \cdot 0$ & $41 \cdot 7 \pm 2 \cdot 8$ \\
\hline L 1930 & $\widehat{\delta}$ & 119 & 54 & $63 \cdot 4$ & $79 \cdot 8$ & $102 \cdot 8$ & 166 & $86 \cdot 7 \pm 2 \cdot 5$ & $27 \cdot 7 \pm 1 \cdot 8$ \\
\hline , & 우 & 119 & 25 & $59 \cdot 2$ & $73 \cdot 1$ & $109 \cdot 6$ & 211 & $86 \cdot 1 \pm 4 \cdot 1$ & $44 \cdot 8 \pm 2 \cdot 9$ \\
\hline
\end{tabular}

Under the heading of " Weight Distribution " lower and upper size limits are indicated, as are also lower, median, and upper quartiles, these being the sizes below which 25, 50, and 75 per cent of the variates occur in each population, and therefore merely convenient indices of the grouping of each 25 per cent of the variates. The outstanding feature of the distributions is that they are not normal, the median being far below the midpoint of the total range. The populations thus include a majority of small individuals, the sampling among large individuals being more than merely correspondingly inferior in view of the extended distribution above the upper quartile. It is also noticeable that the quartiles of the Lympstone populations are fairly uniform and dissimilar to those of the Cawsand populations. One would be inclined to expect that since the populations are thus rendered statistically distinct, this distinction would be reflected into subsequent correlative findings, as the unit of growth is $1.0 \mathrm{gm}$., that of food 1 per cent of the body-weight at the outset of the experimental period.

The peculiarity of the distributions mentioned above is emphasised by the differences between the medians and the means, $\frac{1}{n} \Sigma(\mathrm{f} . \mathrm{X})$, as is shown in Table 1. The means are in every instance considerably greater than the medians. When probable errors are taken into account, the means are fairly uniform as regards sex, but clearly distinct in the $\mathrm{C}$ and $\mathrm{L}$ groups, even though generally speaking all plaice considered are two-year-olds.

The most convenient measure of dispersion is the standard deviation, 
and since this index is to be used consistently throughout the present paper it is essential first of all to define it as the " square-root of the arithmetic mean of the squares of all deviations, deviations being measured from the arithmetic mean of the observations " (Yule, 4, p. 134). Here, with its standard error, it is

$$
\sigma_{\mathrm{x}}=\sqrt{\left.\overline{\mathrm{n}}_{\mathrm{n}} \overline{\mathrm{f}\left(\mathrm{f} . \mathrm{D}^{2}\right.}\right)} \pm \sqrt{\frac{\sigma_{\mathrm{x}}}{\overline{2 \mathrm{n}}}}
$$

It can be converted readily into the mean deviation, $\frac{1}{n}(f . D)$ irrespective of the sign of $\mathrm{D}$, by multiplying by $\cdot 7979$, the standard error into the probable error of the determination by multiplying by $\cdot 6745$. The meaning of the index has been admirably illustrated by Mr. Ford (Ford,* 3, p. 256).

In Table 1 it is seen that, with the exception of the L. 1930 of population, standard deviations happen to form an ascending series from the top of the table to the bottom. The degree of dispersion of body-weights is thus greater in L. than in C. groups, as in the case of means.

It is to be observed, however, that the degree of dispersion is not a reliable index of growth, since maintained individuals of all sizes are included in the populations.

\section{Growth Data.}

Examination of the columns under the heading "Distribution of Weight Changes " in Table 2 will serve to indicate that in all populations

\section{TABLE 2.}

\section{Growth Data.}

\begin{tabular}{|c|c|c|c|c|c|c|c|c|c|}
\hline \multirow{4}{*}{$\begin{array}{l}\text { Population. } \\
\text { C } 1929\end{array}$} & \multirow[b]{3}{*}{ Sex. } & \multicolumn{6}{|c|}{ Distribution of Weight Changes (gm.). } & \multirow{3}{*}{$\begin{array}{c}\text { Mean } \\
\text { Growth (gm.) } \\
\left(\bar{x} \pm \frac{\sigma}{\sqrt{\bar{n}}}\right)\end{array}$} & \multirow{2}{*}{$\begin{array}{c}\text { Standard } \\
\text { Deviation (gm.) } \\
\left( \pm \sigma_{\mathrm{x}} \pm \frac{\sigma_{\mathrm{x}}}{\sqrt{2 \mathrm{n}}}\right)\end{array}$} \\
\hline & & $\begin{array}{l}\text { No. } \\
\text { of }\end{array}$ & Lower & $\begin{array}{l}\text { Lower } \\
\text { Quartile }\end{array}$ & Median & $\begin{array}{c}\text { Upper } \\
\text { Quartile }\end{array}$ & Upper & & \\
\hline & & $\begin{array}{l}\text { Fish: } \\
153\end{array}$ & $\begin{array}{l}\text { Limit. } \\
-6\end{array}$ & $\begin{array}{l}\text { Q1. } \\
-0.6\end{array}$ & $\begin{array}{l}\text { Q2. } \\
0.9\end{array}$ & $\begin{array}{l}\text { Q3. } \\
2.9\end{array}$ & $\begin{array}{l}\text { Limit. } \\
13\end{array}$ & & $3.9+0.9$ \\
\hline & $\underline{G}$ & 161 & -7 & $-0 \cdot 2$ & 0.8 & $3 \cdot 1$ & 14 & $\begin{array}{l}1 \cdot 3=0 \cdot 3 \\
1 \cdot 6+0 \cdot 3\end{array}$ & $\begin{array}{l}3 \cdot 2 \pm 0 \cdot 2 \\
3 \cdot 3+0 \cdot 2\end{array}$ \\
\hline C 1930 & $\hat{\delta}$ & 163 & -5 & $0 \cdot 0$ & $1 \cdot 3$ & $3 \cdot 4$ & $12 \%$ & $1 \cdot 9 \pm 0 \cdot 2$ & $3 \cdot 0 \pm 0 \cdot 2$ \\
\hline & 우 & 171 & -5 & $-0 \cdot 3$ & $1 \cdot 4$ & $3 \cdot 6$ & 11 & $1 \cdot 7 \pm 0 \cdot 2$ & $3 \cdot 1 \pm 0 \cdot 2$ \\
\hline L 1929 & $\hat{o}$ & 100 & -7 & $-1 \cdot 2$ & $1 \cdot 1$ & $7 \cdot 5$ & $17 \dagger$ & $2 \cdot 7 \pm 0 \cdot 6$ & $6 \cdot 0 \pm 0 \cdot 4$ \\
\hline & 우 & 101 & -8 & $-1 \cdot 1$ & $0 \cdot 7$ & $7 \cdot 9$ & 22 & $3 \cdot 2 \pm 0 \cdot 7$ & $6 \cdot 6 \pm 0 \cdot 5$ \\
\hline L 1930 & $\hat{o}$ & 106 & -7 & $-0 \cdot 7$ & $0 \cdot 9$ & $3 \cdot 7$ & $11+\dagger$ & $1 \cdot 7 \pm 0 \cdot 4$ & $4 \cdot 1 \pm 0 \cdot 3$ \\
\hline & 우 & 107 & -8 & -0.2 & $1 \cdot 4$ & $4 \cdot 9$ & $12 *$ & $2 \cdot 7 \pm 0 \cdot 5$ & $5 \cdot 0 七 0 \cdot 3$ \\
\hline
\end{tabular}

\footnotetext{
$\dagger 1$ observation $25 \mathrm{gm}$.

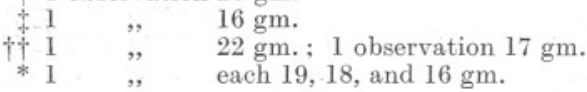

* In all subsequent references, whether in tables or text, the error of the standard deviation and other statistical characteristics cited is the standard error, which it will be remembered is greater than the probable error of the determination. 
weight losses reaching 5-8 gm. occur in 25 per cent of cases, while in 50 per cent of cases weight increases never exceed $1.4 \mathrm{gm}$., and maximum increases may be as low as $0.7 \mathrm{gm}$. These latter cases clearly include the vast majority of maintained individuals, freely-growing individuals forming the bulk of the upper 50 per cent of each population. In this respect the C. and L. groups are fairly uniform whereas the upper quartiles are generally higher in the L. groups, which indicates at once a higher degree of growth in approximately half the total number of freely-growing individuals. This feature is expecially well marked during 1929. As will now be expected, mean growth is much greater among the L. groups, ranging from 1.7-3.2 gm. as against a range of $1 \cdot 3-1 \cdot 9 \mathrm{gm}$. among the C. groups. Dispersion in the upper parts of the populations is also greater, medians and upper quartiles ranging from $3 \cdot 7-25 \mathrm{gm}$. in the L. groups as against a range of $2 \cdot 9-16 \mathrm{gm}$. in the C. groups. Differences of degree of dispersion are best shown with respect to standard deviations, however, which vary between $4 \cdot 1$ and $6 \cdot 6 \mathrm{gm}$. in the L. populations and between $3 \cdot 0$ and $3 \cdot 3 \mathrm{gm}$. in the $\mathrm{C}$. populations, with insignificant standard errors in each case. Clearly, degree of growth is distinctly different in the two sets of populations.

\section{Food Data.}

The principal features of the distribution of food quantities are shown in Table 3. The median is clearly much lower in the case of the L. populations, excepting L. 1930 or. The figures show that 50 per cent of the first

\section{TABLE 3.}

\section{Food Data}

\begin{tabular}{|c|c|c|c|c|c|c|c|c|c|}
\hline \multirow[b]{2}{*}{ Population. } & \multirow[b]{2}{*}{ Sex. } & & \multicolumn{5}{|c|}{$\begin{array}{c}\text { Distribution of Food Quantities ( }=\% \text { ages of Bd.-wt.) } \\
\text { Upper }\end{array}$} & \multirow{2}{*}{$\begin{array}{c}\text { Mean } \\
\text { Ration \% } \\
\left(\overline{\bar{y}} \pm \frac{\sigma_{y}}{\sqrt{ }-}\right)\end{array}$} & \\
\hline & & $\begin{array}{c}\text { No. } \\
\text { of } \\
\text { Fish. }\end{array}$ & $\begin{array}{l}\text { Lower } \\
\text { Limit. }\end{array}$ & $\begin{array}{c}\text { Lower } \\
\text { Quartile } \\
\text { Q1. }\end{array}$ & $\begin{array}{c}\text { Median } \\
\text { Q2. }\end{array}$ & $\begin{array}{c}\text { Upper } \\
\text { Quartile } \\
\text { Q3. }\end{array}$ & $\begin{array}{l}\text { Upper } \\
\text { Limit. }\end{array}$ & & $\begin{array}{l}\text { Deviation } \\
\left. \pm \sigma_{y} \pm \frac{\sigma_{y}}{\sqrt{2 n}}\right)\end{array}$ \\
\hline C 1929 & $\hat{\jmath}$ & 153 & 1 & $23 \cdot 3$ & $41 \cdot 9$ & $118 \cdot 6$ & 266 & $73 \cdot 7 \pm 5 \cdot 1$ & $63 \cdot 0 \pm 3 \cdot 6$ \\
\hline & 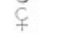 & 161 & 2 & $22 \cdot 6$ & $38 \cdot 4$ & $96 \cdot 0$ & 249 & $59 \cdot 9 \pm 3 \cdot 9$ & $49 \cdot 2 \div 2 \cdot 7$ \\
\hline C 1930 & $\hat{o}$ & 163 & 9 & $21 \cdot 3$ & $45 \cdot 4$ & $81 \cdot 6$ & 200 & $56 \cdot 1 \pm 3 \cdot 2$ & $41 \cdot 1 \pm 2 \cdot 3$ \\
\hline & 우 & 171 & 3 & $18 \cdot 5$ & $41 \cdot 7$ & $80 \cdot 5$ & 257 & $58 \cdot 7 \pm 4 \cdot 0$ & $52 \cdot 4 \pm 2 \cdot 8$ \\
\hline L 1929 & $\hat{o}$ & 100 & 2 & $15 \cdot 1$ & $25 \cdot 0$ & $102 \cdot 5$ & 249 & $56 \cdot 2 \pm 5 \cdot 3$ & $53 \cdot 4 \pm 3 \cdot 8$ \\
\hline & 우 & 101 & 3 & $14 \cdot 6$ & $24 \cdot 7$ & $92 \cdot 5$ & 226 & $53 \cdot 1 \pm 5 \cdot 4$ & $53 \cdot 7 \pm 3 \cdot 8$ \\
\hline L 1930 & $\hat{o}$ & 106 & 6 & $18 \cdot 3$ & $29 \cdot 2$ & $63 \cdot 4$ & 120 & $40 \cdot 2 \pm 2 \cdot 5$ & $25 \cdot 7 \pm 1 \cdot 8$ \\
\hline, & 우 & 107 & 2 & $18 \cdot 8$ & $42 \cdot 3$ & $65 \cdot 9$ & 116 & $44 \cdot 4 \pm 2 \cdot 6$ & $27 \cdot 0 \pm 1 \cdot 8$ \\
\hline
\end{tabular}

three L. populations took percentages less than $29 \cdot 3,50$ per cent of any C. population taking percentages greater than $38 \cdot 3$. Since the portion of each population receiving such low percentages is largely if not entirely formed of maintained individuals, it follows that the maintenance demands (expressed as percentages of body-weight) at Lympstone were smaller than those at Cawsand. Weight decreases at Lympstone were slightly 
greater than at Cawsand, but apparently not correspondingly so, while temperatures were slightly higher at the former place (Dawes, 1 and 2). But in view of the fact that sizes were much greater at Lympstone it seems safe to infer that such differences in maintenance demands as are noted above are connected with, if not entirely due to, size differences. The inference also receives some support from the much smaller lower quartiles in the L. populations.

Upper quartiles and upper limits are greater in C. populations of a particular year than in L. populations of the corresponding year, especially so during 1930. Standard deviations are considerably greater in the 1929 groups and are generally greater in the C. groups when particular years are considered. The especially low standard deviations of the L. 1930 populations are connected with low growth characteristics, both degree of growth and appetite being smaller during 1930 than during the preceding year.

\section{Correlation between Food and Growth.}

It is evident from the foregoing that both growth in weight and food percentages taken are highly variable. This was clearly indicated also in my previous papers, where it was also shown that similar high variability characterises growth efficiency, i.e. the capacity to utilise food for purposes of growth. But high values of weight increase are generally associated with high food percentages and it is with this association that we are now concerned. Tables $8-15$ are built up by noting the frequency with which particular associations of the $\mathrm{x}$ and $\mathrm{y}$ variables occur, which frequencies are grouped and arranged in arrays to form correlation tables.

The index of correlation is the correlation coefficient $r$, which is a pure number lying between the limits -1 and +1 . It is positive if large values of $\mathrm{x}$ are associated with large values of $\mathrm{y}$, negative if small values of $\mathrm{x}$ are associated with large values of $\mathrm{y}$, and conversely. If the two variables are independent, i.e. if there is no correlation, $r=0$. It is calculated from the formula,

$$
\mathrm{r}=\frac{\mathrm{p}}{\sigma_{\mathrm{x}} \sigma_{\mathrm{y}}}
$$

where $\sigma_{\mathrm{x}}$ and $\sigma_{\mathrm{y}}$ are the standard deviations of $\mathrm{x}$ and $\mathrm{y}$ variables and where $p$ is a measure of variance, being the product of deviations from the arbitrary origin minus the product of the difference between arbitrary and true means, i.e.

$$
\mathrm{p}=\frac{\Sigma(\mathrm{x}-\overline{\mathrm{x}})(\mathrm{y}-\overline{\mathrm{y}})}{\mathrm{n}}-\left(\mathrm{D}_{\mathrm{x}} \mathrm{D}_{\mathrm{y}}\right)
$$


Taking the C. 1929 populations and making use of the tables cited, we have :-

(Table 8)

$$
\begin{aligned}
& \mathrm{D}_{\mathrm{x}}=\frac{51}{153}=\cdot 3 \mathrm{gm} . \\
& \mathrm{D}_{\mathrm{y}}=\frac{-20}{153}=-\cdot 1307 \times 10 \%
\end{aligned}
$$

(Table 2)

$$
\sigma_{\mathrm{x}}=3 \cdot 178 \text { (calculated value) }
$$

(Table 3)

$$
\begin{aligned}
& \sigma_{y}=6.302 \times 10 \% \\
& p=\frac{1498}{153}-(\cdot 3 \times-\cdot 1307) \\
& =9 \cdot 792+\cdot 044 \\
& =9 \cdot 836
\end{aligned}
$$$$
r=\frac{9 \cdot 836}{3.178 \times 6 \cdot 302}=\cdot 4912
$$

$$
\begin{aligned}
& \text { (Table 9) } \quad[\text { [q] } \\
& \begin{aligned}
\mathrm{D}_{\mathrm{x}} & =\frac{97}{161}=\cdot 6030 \mathrm{gm} . \\
\mathrm{D}_{\mathrm{y}} & =\frac{-82}{161}=-.5093 \times 10 \%
\end{aligned}
\end{aligned}
$$

\section{$[q]$}

$$
\sigma_{\mathrm{x}}=3 \cdot 354 \mathrm{gm} \text {. }
$$

$$
\begin{aligned}
\sigma_{\mathrm{y}} & =4.916 \times 10 \% \\
\mathrm{p} & =\frac{1264}{161}-(.603 \times-.5093) \\
& =7.852+.307 \\
& =8.159
\end{aligned}
$$

$\mathrm{r}=\frac{8 \cdot 159}{3 \cdot 354 \times 4 \cdot 916}=\cdot 4950$

Data for the remaining populations were treated in the same way, using Tables 2 and 3 and 10-15, and the list of correlation coefficients presented in Table 4 was obtained by the use of the values of $p$ shown. It is seen that in every case there occurs a moderately high degree of correlation. The standard errors are greater in the case of $\mathrm{C}$. populations but are nowhere of sufficiently high value to preclude the probability of fairly high correlation not due to mere chance. The values of $\mathrm{r}$ are highest among L. populations, lowest among the C. populations, higher during 1930 in C. groups, during 1929 in L. groups. There is close similarity for the sexes during any particular year.

The diagrams in Figs. 1 and 2 are made by representing the frequencies each by a single ring in its appropriate position. They refer to the C. 1929 populations ( $\delta$ and + ) and they indicate the degree of correlation diagrammatically. The regression lines shown are drawn in after calculation of the regression coefficients from the formulæ

$$
\mathrm{b}_{\mathrm{x}}=\frac{\mathrm{r} \sigma_{\mathrm{x}}}{\sigma_{\mathrm{y}} \times 10} ; \quad \mathrm{b}_{\mathrm{y}}=\frac{\mathrm{r} \sigma_{\mathrm{y}} \times 10}{\sigma_{\mathrm{x}}}
$$

The lines cut each other in the means $\bar{x}$ and $\bar{y}$ and the angle they make with each other indicates the degree of correlation ; an angle of approximately $90^{\circ}$ would represent independency of the variables. 
Continuing the examples previously taken (C. 1929), we have :-

[0]

$$
\begin{aligned}
& \mathrm{b}_{\mathrm{x}}=\frac{\cdot 4912 \times 3 \cdot 178}{63.02}=\cdot 0248 \\
& \mathrm{~b}_{\mathrm{y}}=\frac{\cdot 4912 \times 63.02}{3.178}=9 \cdot 738
\end{aligned}
$$

[?]

$$
\begin{aligned}
& \mathrm{b}_{\mathrm{x}}=\frac{\cdot 495 \times 3 \cdot 354}{49 \cdot 16}=\cdot 0338 \\
& \mathrm{~b}_{\mathrm{y}}=\frac{\cdot 495 \times 49 \cdot 16}{3 \cdot 354}=7 \cdot 256
\end{aligned}
$$

$b_{x}$ is the regression of $x$ on $y$, i.e. the regression function given by the

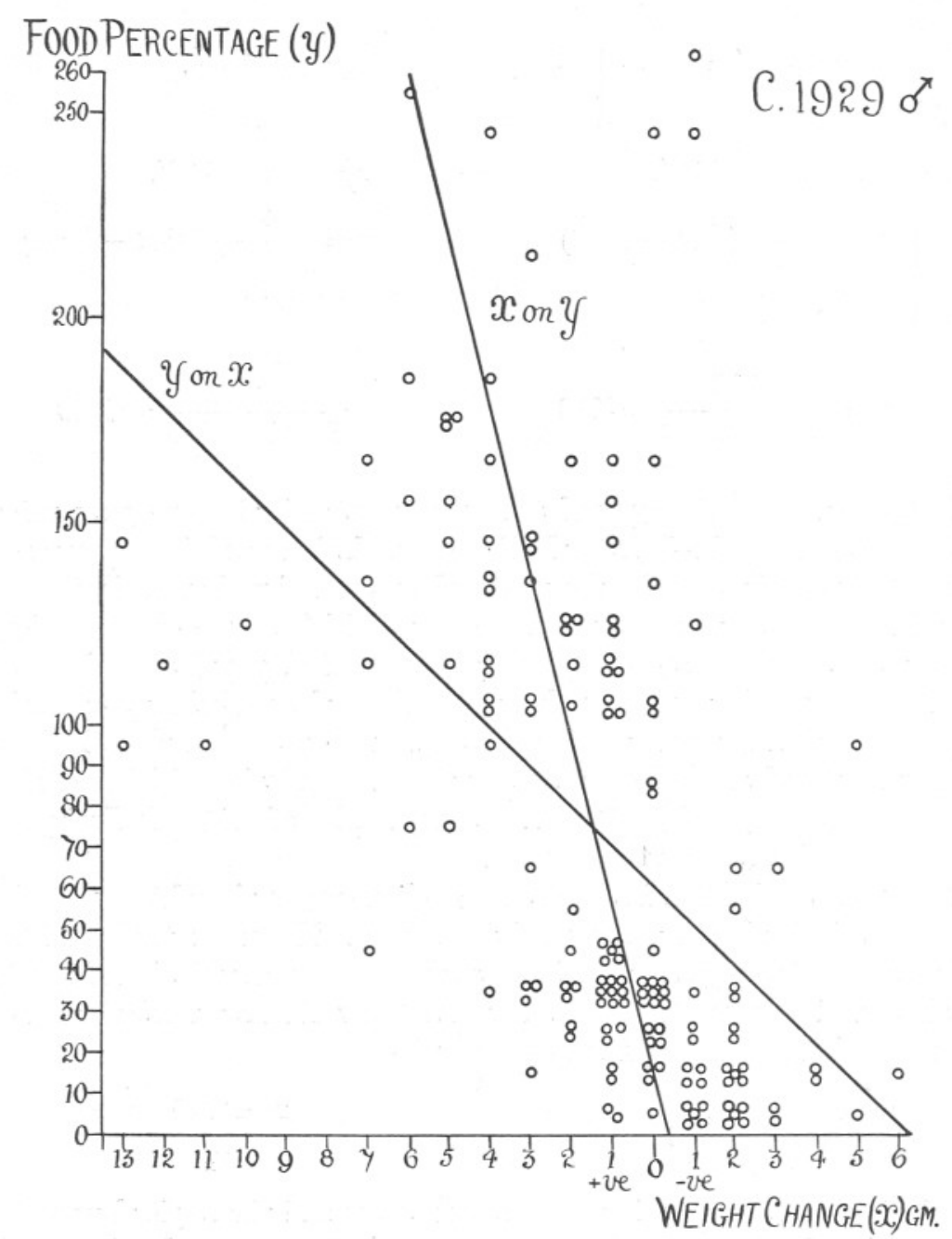

FIG. 1.-Correlation diagram for the male plaice population of Cawsand, 1929. The regression lines were drawn in lastly and are based upon the regression coefficients calculated. The diagram is a graphical presentation of Table 8 . 
equation $\mathrm{x}=\overline{\mathrm{x}}-\mathrm{b}_{\mathrm{x}}(\mathrm{y}-\overline{\mathrm{y}})$, by the regression of $\mathrm{y}$ on $\mathrm{x}$, i.e. the regression function given by the equation $y=\bar{y}-b_{y}(x-\bar{x})$. Since the primary aim is to deduce weight increase $(x)$ from available food percentage $(y)$, the more important regression line from the point of view of this work is that

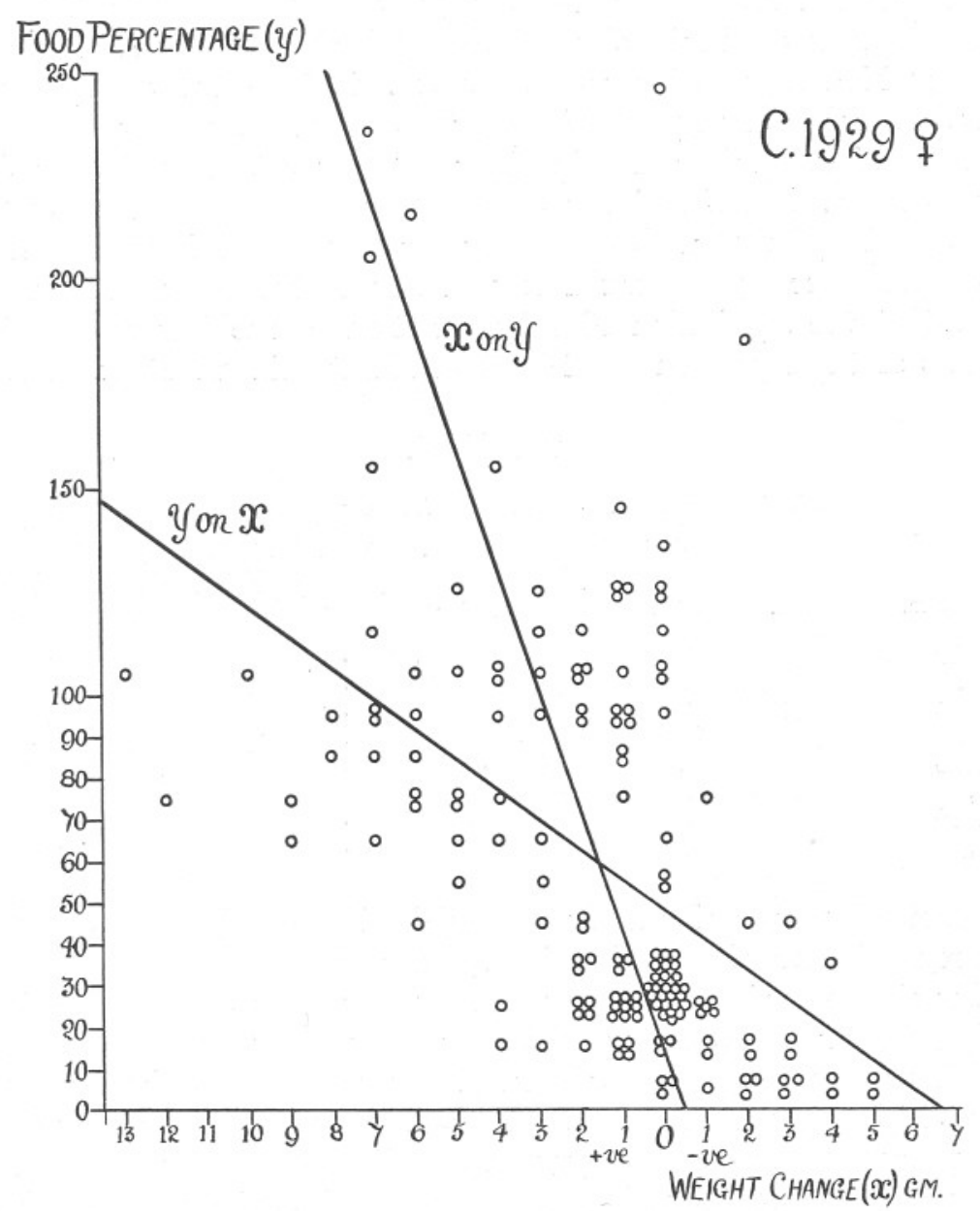

FIG. 2.-Correlation diagram for the female plaice population of Cawsand, 1929 , with regression lines drawn in as in Fig. 1 . The diagram is a graphical presentation of Table 9 .

of $x$ on $y$. The regression coefficient $b_{x}$ indicates the order of change in $x$, i.e. weight increase or decrease, resulting on the average from unit change in $y$, i.e. food percentage, since $x=b_{x} y$. Similarly, $b_{y}$ indicates the order of change in $y$ with unit change in $\mathrm{x}$. In the above example the slope of the regression line of $\mathrm{x}$ on $\mathrm{y}$ is appreciably steeper in the case of males 
where $b_{x}$ is smaller. Similarly, the slope of the regression line of $y$ on $x$ is correspondingly steeper, since the correlation coefficients are identical. This is shown diagrammatically in Figs. 1 and 2, where the regression lines are drawn into the correlation dot diagrams.

The regression coefficients for all populations were calculated by the method illustrated in the above example and they are shown in Table 4 along with corresponding standard errors. It is seen that only in the instance of the C. 1929 populations are the differences between the regression coefficients of the sexes significant, when standard errors are taken into account. Even in this instance some of this significance is lost when it is considered that the chances of the true values lying within $\pm 2 \times$ standard error are approximately merely of the order of 20 to 1, and that the application of this correction in one instance renders values of the regression coefficients confluent. In all other cases it

TABLE 4.

Regression and Correlation Coefficients.

\begin{tabular}{|c|c|c|c|c|c|}
\hline Population. & Sex. & $\begin{array}{l}\text { Product of } \\
\text { Deviations } \\
\text { from Mean } \\
\text { (p). }\end{array}$ & $\begin{array}{l}\text { Correlation Coeff. } \\
\mathrm{r}=\frac{\mathrm{p}}{\frac{\sigma_{\mathrm{x}} \sigma_{\mathrm{y}}}{10}} \pm \frac{1-\mathrm{r}^{2}}{\sqrt{\mathrm{n}}}\end{array}$ & 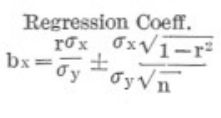 & $\begin{array}{c}\text { Regression Coeff. } \\
\text { r } \sigma_{y} \sigma_{y} \sqrt{1-r^{2}} \\
\text { by }=\frac{\sigma_{x}}{\sigma_{x}} \frac{\sqrt{n}}{\sigma_{n}}\end{array}$ \\
\hline C 1929 & $\hat{o}$ & $9 \cdot 84$ & $0 \cdot 49 \pm .06$ & $\cdot 025 \pm \cdot 003$ & $9 \cdot 7 \pm 1 \cdot 4$ \\
\hline & 우 & $8 \cdot 16$ & $0 \cdot 49 \pm .06$ & $.034 \pm .005$ & $7 \cdot 3 \pm 1 \cdot 0$ \\
\hline C 1930 & $\hat{0}$ & $7 \cdot 89$ & $0 \cdot 63 \pm \cdot 03$ & $.047 \pm .005$ & $8.5 \pm 0.9$ \\
\hline & $\underline{+}$ & $10 \cdot 35$ & $0 \cdot 64 \pm \cdot 03$ & $\cdot 038 \pm \cdot 004$ & $10 \cdot 8 \pm 1 \cdot 0$ \\
\hline L 1929 & $\hat{0}$ & $25 \cdot 09$ & $0 \cdot 78 \pm \cdot 04$ & $\cdot 088 \pm \cdot 007$ & $6.9 \pm 0.6$ \\
\hline & 우 & $24 \cdot 97$ & $0 \cdot 70 \neq \cdot 05$ & $\cdot 086+009$ & $5.8+0.9$ \\
\hline L 1930 & 0 & $6 \cdot 47$ & $0 \cdot 63 \pm \cdot 04$ & $\cdot 100 \pm \cdot 012$ & $3.9+0.5$ \\
\hline, & 우 & $8 \cdot 19$ & $0 \cdot 61 \pm \cdot 04$ & $\cdot 112 \pm \cdot 014$ & $3 \cdot 3 \pm 0 \cdot 4$ \\
\hline
\end{tabular}

is practically certain that no difference exists between the sexes as regards the regression functions during either year at either place.

But these functions vary slightly from year to year and vary considerably between the $\mathrm{C}$. and $\mathrm{L}$. populations, the Cawsand populations yielding much steeper regression lines than the Lympstone ones, and thus indicating a higher growth efficiency. And although variable factors such as temperature might conceivably produce such differences in the regression functions, there appear to be good grounds for believing that size differences, which are well marked between the $\mathrm{C}$. and $\mathrm{L}$. populations as we have seen, are the factors principally involved. That the differences in the regression functions are significant is shown in Table 4, the greatest value for $b_{x}$ in any C. population being $\cdot 047$, while in any $L$. population the least value of the corresponding coefficient is $\cdot 086$, with an insignificant standard error in each case. These results are shown graphically in Figs. 3-5, where the regression lines for the remaining populations are presented. 
In all the above cases it has been assumed that the regression lines are linear, an assumption which is by no means justifiable unless the approximation to linearity is measured and found to be reasonably close. Such a measure of the closeness to linearity is available in the form of the "correlation ratio" of Professor Pearson $\left(\eta_{x y}\right)$. This ratio, which is the correlation ratio of $\mathrm{x}$ on $\mathrm{y}$, " measures the approach of values of $\mathrm{x}$

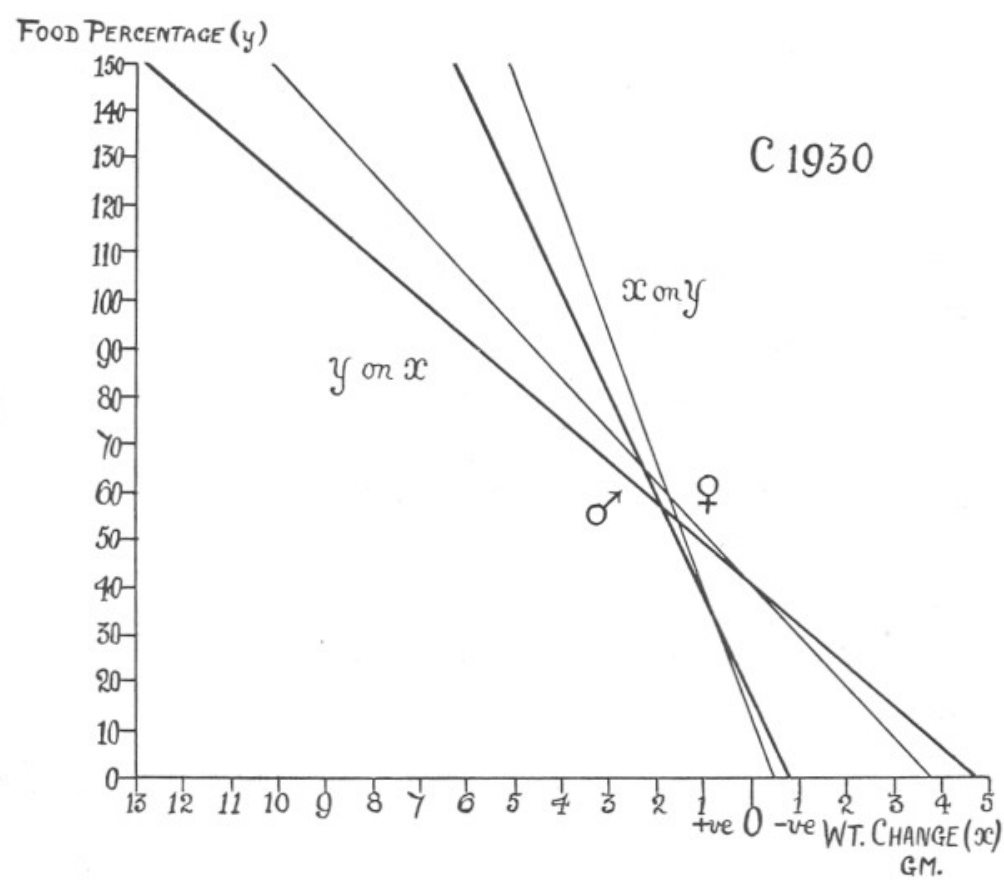

FIG. 3.-Diagram showing the positions and slopes of the regression lines for male and female plaice populations of Cawsand, 1930. Although this is not a correlation diagram, yet it is strictly based upon Tables 10 and 11 .

associated with given values of y to a single valued relationship of any form " (Yule, 4, p. 205). Each table provides two such ratios, the second being $\eta_{\mathrm{yx}}$ or the correlation ratio of $\mathrm{y}$ on $\mathrm{x}$, the significance of which will be clear.

The correlation ratios for the various populations were calculated from the formulæ :-

$$
\eta_{\mathrm{xy}}=\frac{\sigma_{\mathrm{mx}}}{\sigma_{\mathrm{x}}} ; \quad \eta_{\mathrm{yx}}=\frac{\sigma_{\mathrm{my}}}{\sigma_{\mathrm{y}}}
$$

where $\sigma_{\mathrm{x}}$ and $\sigma_{\mathrm{y}}=$ standard deviations of $\mathrm{x}$ and $\mathrm{y}$ respectively, $\sigma_{\mathrm{mx}}$ and $\sigma_{\mathrm{my}}=$ standard deviation of the means of the $\mathrm{x}$ and $y$ arrays, respectively.

The way in which the formulæ are derived is shown in loc. cit. and it is 
sufficient here merely to indicate that $\eta_{\mathrm{xy}}$ and $\eta_{\mathrm{yx}}$ are invariably greater than the correlation coefficient $r$, and that the difference between these quantities indicates the departure from linearity, $\eta^{2}-\mathrm{r}^{2}$ measuring the divergence of the actual line through the means of the arrays from the line of regression. At the same time, it should be observed that " owing to

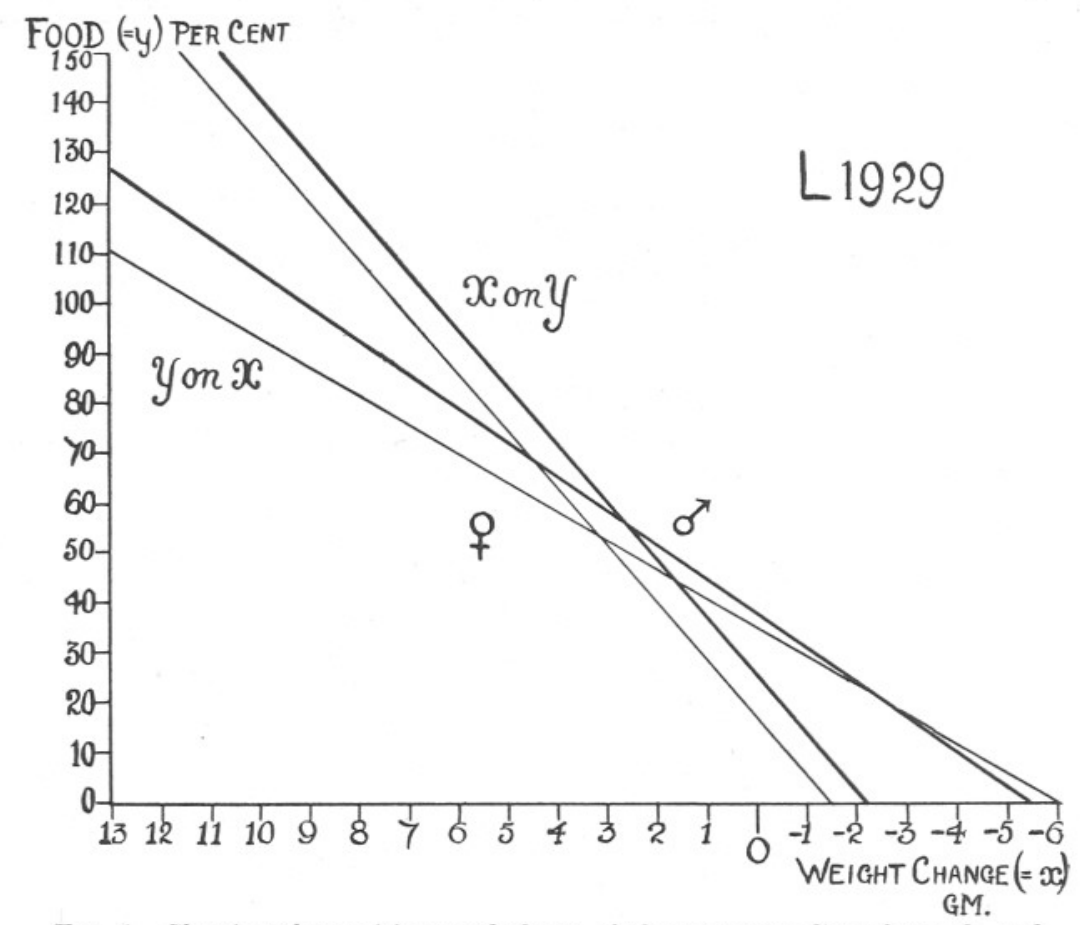

FIg. 4.- Showing the positions and slopes of the regression lines for male and female plaice populations of Lympstone, 1929, based upon Tables 12 and 13.

fluctuations of sampling, $\mathrm{r}$ and $\eta$ are almost certain to differ slightly, even though the regression may be truly linear (Yule, 4, p. 206).

\section{TABLE 5.}

Data for Estimating the Departure of the Regression LINES FROM LINEARITY.

\begin{tabular}{|c|c|c|c|c|c|c|c|c|c|c|}
\hline \multirow[b]{2}{*}{ Population. } & \multirow{2}{*}{\multicolumn{3}{|c|}{$\begin{array}{l}\text { Standard Devia- } \\
\text { tions of Means } \\
\text { of Arrays. } \\
\sigma \mathrm{mx}\end{array}$}} & \multicolumn{2}{|c|}{$\begin{array}{c}\text { Standard } \\
\text { Deviations (gm.). }\end{array}$} & \multicolumn{2}{|c|}{$\begin{array}{l}\text { Correlation } \\
\text { Ratios. }\end{array}$} & \multirow[t]{2}{*}{$\begin{array}{l}\text { Correla- } \\
\text { tion } \\
\text { Coeff. } \\
\text { r }\end{array}$} & \multirow{2}{*}{\multicolumn{2}{|c|}{$\eta_{x y^{2}}-r^{2} \eta_{y x^{2}}-r^{2}$}} \\
\hline & & & & $\sigma_{\mathrm{X}}$ & & $\eta_{\mathrm{Xy}}$ & $\eta_{y x}$ & & & \\
\hline C 1929 & 0 & $2 \cdot 2$ & $37 \cdot 5$ & $3 \cdot 2$ & $63 \cdot 0$ & $\cdot 70$ & .60 & $\cdot 49$ & $\cdot 25$ & $\cdot 12$ \\
\hline & 온 & $2 \cdot 3$ & $27 \cdot 1$ & $3 \cdot 3$ & $49 \cdot 2$ & .71 & .55 & .49 & $\cdot 26$ & .06 \\
\hline C 1930 & $\delta$ & $2 \cdot 1$ & $30 \cdot 1$ & $3 \cdot 0$ & $40 \cdot 1$ & $\cdot 70$ & $\cdot 73$ & .63 & .09 & $\cdot 14$ \\
\hline & 우 & $2 \cdot 4$ & $36 \cdot 7$ & $3 \cdot 1$ & $52 \cdot 4$ & .76 & .70 & .64 & $\cdot 19$ & .08 \\
\hline L 1929 & $\hat{0}$ & $5 \cdot 1$ & $49 \cdot 6$ & $6 \cdot 0$ & $53 \cdot 4$ & $\cdot 84$ & $\cdot 93$ & $\cdot 78$ & $\cdot 10$ & $\cdot 26$ \\
\hline & 우 & $5 \cdot 6$ & $48 \cdot 5$ & $6 \cdot 6$ & $53 \cdot 7$ & .86 & .90 & 70 & $\cdot 25$ & $\cdot 32$ \\
\hline L 1930 & 0 & $2 \cdot 7$ & $18 \cdot 9$ & $4 \cdot 1$ & $25 \cdot 7$ & $\cdot 67$ & $\cdot 74$ & .63 & .05 & $\cdot 15$ \\
\hline , & 우 & $3 \cdot 4$ & $19 \cdot 7$ & $5 \cdot 0$ & $27 \cdot 0$ & $\cdot 67$ & $\cdot 73$ & $\cdot 61$ & $\cdot 08$ & $\cdot 16$ \\
\hline
\end{tabular}


Values have been obtained for the correlation ratios of all populations and are shown in Table 5, together with the standard deviations from which they were calculated. If these values are compared with those of the regression coefficients, which are also shown in the table, it will be seen that in some cases the departure from linearity is fairly slight. In 4 instances, $\eta_{x y}{ }^{2}-r^{2} \equiv \cdot 10$ although in other instances it increases to $\cdot 26$; in 2 instances, $\eta_{\mathrm{yx}}{ }^{2}-\mathrm{r}^{2} \equiv \cdot 08$ while in others it ranges from $\cdot 12$ to $\cdot 32$. During 1930 the approach to linearity of the regression lines is much closer than during 1929, but if it is justifiable to assume linearity in one

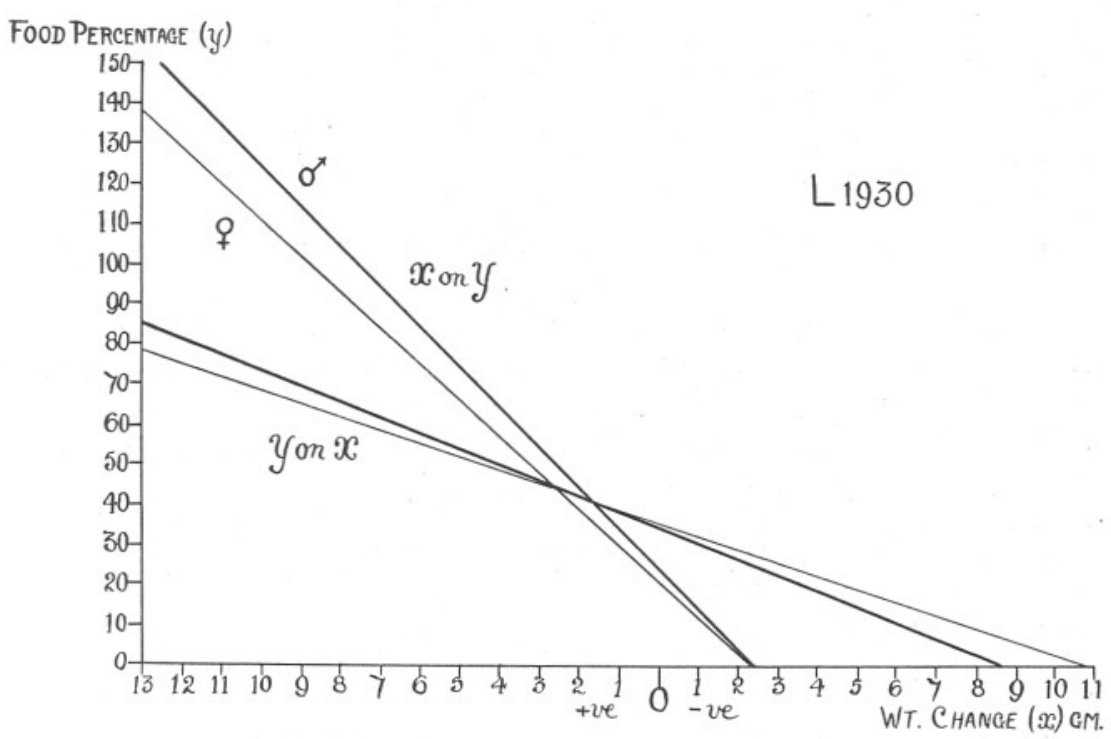

Fia. 5.-Showing the positions and slopes of the regression lines for male and female plaice populations of Lympstone, 1930. Based upon Tables 14 and 15.

instance it is justifiable in others, especially since the aim of the work is to obtain only approximate indices, and although the regression lines strictly are not straight it is sufficient for our purpose to assume that they are.

By substituting mean values and regression coefficients in the regression equations, equations of the form $\mathrm{x}=\mathrm{b}_{\mathrm{x}} \mathrm{y}+$ const. and $\mathrm{y}=\mathrm{b}_{\mathrm{y}} \mathrm{x}+$ const. are obtained. A set of pairs of such equations are provided in Table 6. The constants in equations (1) indicate how far the regression lines of $\mathrm{x}$ on $\mathrm{y}$ are displaced to the right in Figures 1-5, and it is seen that the C. and L. populations show striking differences in this respect, the constant being at least thrice the $\mathrm{C}$. value in the corresponding $\mathrm{L}$. population. In equations (2) the constants show how far the regression line of $\mathrm{y}$ on $\mathrm{x}$ is 
displaced vertically in the same figures, and in this case there is no wellmarked difference other than that shown by the C. 1929 populations, especially the male one.

\section{TABLE 6 .}

Regression Equations of the Form $\mathrm{x}=\mathrm{b}_{\mathrm{x}} \mathrm{y}+$ const. AND $\mathrm{y}=\mathrm{b}_{\mathrm{y}} \mathrm{x}+$ const., with values of Each variate When the value of the OTHER IS ZERO.

\begin{tabular}{|c|c|c|c|c|c|c|c|}
\hline Population. & Sex. & $\begin{array}{c}\text { Equation (1) } \\
\mathbf{x}=(\mathrm{gm} .)\end{array}$ & $\begin{array}{c}\text { Equation (2) } \\
y=(\%)\end{array}$ & $\begin{array}{c}\text { In }(1), \\
\text { when } \\
x=0 \\
y=(\%)\end{array}$ & $\begin{array}{c}\text { In (2). } \\
\text { when } \\
y=0 \\
x=(\mathrm{gm} .)\end{array}$ & $\begin{array}{l}\text { In (1), } \\
\text { when } \\
x=05 \\
y=(\%)\end{array}$ & $\begin{array}{c}\text { In (1), } \\
\text { when } \\
x=1 \cdot 0 \\
y=(\%)\end{array}$ \\
\hline C 1929 & $\hat{\sigma}$ & $.025 \mathrm{Y}-.49$ & $9 \cdot 7 \mathrm{X}+60 \cdot 7$ & 19 & -6 & 40 & 60 \\
\hline & 우 & $\cdot 034 \mathrm{Y}-\cdot 42$ & $7 \cdot 3 \mathrm{X}+48 \cdot 3$ & 12 & & 27 & 42 \\
\hline C 1930 & ơ & $.047 \mathrm{Y}-\quad \cdot 73$ & $8.5 X+40 \cdot 0$ & 16 & & 26 & 37 \\
\hline & 우 & $.038 Y-\cdot 47$ & $10.8 \mathrm{X}+39.8$ & 12 & -4 & 26 & 39 \\
\hline L 1929 & 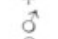 & $.088 Y-2 \cdot 19$ & $6.9 \mathrm{X}+37 \cdot 1$ & 25 & -5 & 31 & 36 \\
\hline & 우 & $\cdot 086 \mathrm{Y}-1 \cdot 41$ & $5 \cdot 8 \mathrm{X}+34 \cdot 8$ & 16 & -6 & 22 & 28 \\
\hline L 1930 & $\hat{\sigma}$ & $\cdot 100 \mathrm{Y}-2 \cdot 34$ & $3 \cdot 9 \mathrm{X}+33 \cdot 6$ & 23 & -9 & 28 & 33 \\
\hline , & 우 & $\cdot 112 \mathrm{Y}-2 \cdot 31$ & $3.3 \mathrm{X}+35 \cdot 5$ & 21 & -11 & 25 & 30 \\
\hline
\end{tabular}

If in equations ( 1 ) we make $\mathrm{x}=0$, the evaluation of $\mathrm{y}$ will then provide a measure of maintenance requirements in terms of percentage of the initial body-weight. A list of such evaluations of $\mathrm{y}$ are shown in Col. 5 of Table 6, and are seen to provide greater indices in males than in females and at Lympstone than at Cawsand. This latter is contrary to previous findings both in my previous paper and in the present one where quartiles of the $y$ variate are discussed, and it calls for an explanation.

The figures in Col. 5 of Table 6 are misleading unless it is borne in mind that there is a significant difference in the steepness of the regression lines of the C. and L. populations. These lines are much steeper in the C. populations, which implies that the change in y corresponding to unit change in $\mathrm{x}$ is greater in this case. When $\mathrm{x}=0, \mathrm{y}$ is greater in the $\mathrm{L}$. than in the $\mathrm{C}$. populations, i.e. maintenance demands, as percentages, are greater. But when $\mathrm{x}=\cdot 5$ the significance of the difference is lost, and when $\mathrm{x}=1 \cdot 0$ the values of $\mathrm{y}$ are considerably greater in the $\mathrm{C}$. populations, as is shown in Table 6, especially during 1929. For pure maintenance, the larger L. individuals appear to require slightly higher food percentages than do the C.individuals, but this result is more apparent than real, since if very small increases are considered the reverse is the case. Increases greater than $.5 \mathrm{gm}$. required greater food percentages in the case of $\mathrm{C}$. than in the case of L. populations, as is shown by a study of the regression equations.

The above-mentioned feature of relative efficiency in the C. and L. populations is brought out rather better in Table 7. The ratio $\mathrm{b}_{\mathrm{x}} \mathrm{X}^{100} / \overline{\mathrm{X}}$ 


\section{TABLE 7.}

\begin{tabular}{|c|c|c|c|c|c|c|c|c|}
\hline $\mathrm{R}_{\mathrm{EG}}$ & $\begin{array}{r}\mathrm{N} \text { Co } \\
100\end{array}$ & $\begin{array}{l}\left.b_{x}\right) A \\
A\end{array}$ & $\begin{array}{l}\text { in } 1 \mathrm{I} \\
\mathrm{D} 1\end{array}$ & $\begin{array}{l}\text { RRED } \\
\left(b_{y}\right)\end{array}$ & & VELY. & PlaICE & OF \\
\hline ation. & $\begin{array}{c}\mathrm{C} 1929 \\
\hat{O}\end{array}$ & $\begin{array}{c}\mathrm{C} 1929 \\
\text { ㅇ }\end{array}$ & C $\begin{array}{c}1930 \\
0\end{array}$ & $\begin{array}{c}\mathrm{C} 1930 \\
+\end{array}$ & $\begin{array}{c}\text { L } 1929 \\
\sigma^{2}\end{array}$ & $\begin{array}{c}\text { L } 1929 \\
\stackrel{+}{q}\end{array}$ & $\begin{array}{c}\text { L } 1930 \\
\delta\end{array}$ & $\begin{array}{c}\mathrm{L} 1930 \\
\text { 古 }\end{array}$ \\
\hline & $35 \cdot 2$ & $44 \cdot 6$ & $52 \cdot 7$ & $54 \cdot 1$ & $84 \cdot 0$ & $90 \cdot 4$ & $86 \cdot 7$ & $86 \cdot 1$ \\
\hline$\times 100 / \bar{X}$ & $\cdot 07$ & $\cdot 08$ & $\cdot 09$ & $\cdot 07$ & $\cdot 10$ & $\cdot 10$ & $\cdot 12$ & $\cdot 13$ \\
\hline$\sqrt{\mathrm{x}}$ & $\cdot 28$ & $\cdot 16$ & $\cdot 16$ & $\cdot 20$ & $\cdot 08$ & $\cdot 06$ & .04 & .04 \\
\hline
\end{tabular}

indicates the degree of change in $\mathrm{x}$ related to unit change in $\mathrm{y}$ for a standard plaice of $100 \mathrm{gm}$., which change is slightly greater in the L. groups, thus suggesting greater efficiency in these groups. This suggestion is furthered when the ratio $b_{y} / \bar{X}$ is considered, when the degree of change in $y$ per gm. of fish corresponding to unit change in $\mathrm{x}$ is found to be very much greater in the C. groups, i.e. efficiency is not as great.

By making $\mathrm{y}=0$ in equation (2) (Table 6 ) the values of $\mathrm{x}$ obtained indicate the probable weight decreases during starvation for the various populations, these being slightly greater in the L. populations (5-11 gm.) than in the C. populations (4-7 gm.).

\section{L.W. ExperIments.}

It remains to consider briefly the winter experiments carried out at Lympstone during the early months of 1930. They are of especial interest because the individuals used were carried through from the experiments of 1929, which enables the results to bear comparison with those of the L. 1929 populations, thus affording also a comparison between winter and summer performances. The sexes have been grouped together, since the number of individuals of one sex is too small to allow of reliable statistical treatment.

The following size data indicate how closely the L.W. population compares with the L. 1929 ones (see Table 1) :

$$
\begin{aligned}
& {[\overline{\mathrm{x}}] \text { Mean weight : }} \\
& {\left[\sigma_{\mathrm{x}}\right] \text { Standard deviation : }-24 \cdot 6 \pm 2 \cdot 9 \mathrm{gm} .}
\end{aligned}
$$

The principal differences between the populations as regards size of individuals is thus seen to be one of degree of dispersion, this naturally being much smaller in the L.W. populations.

As would be anticipated, growth is much more restricted, as the following figures indicate :

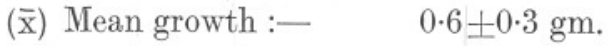

$\left(\sigma_{\mathrm{x}}\right)$ Standard deviation : $-2 \cdot 6 \pm 0 \cdot 2 \mathrm{gm}$.

Mean growth in the case of the L. 1929 populations is roughly five times as great, standard deviation more than twice as great (Table 2). 
Food percentages taken are very substantially smaller.

$(\bar{y})$ Mean food :$18 \cdot 7 \pm 1 \cdot 9$ per cent.

$\left(\sigma_{\mathrm{y}}\right)$ Standard deviation : $-14 \cdot 6 \pm 1 \cdot 3$ per cent.

Each of these values is approximately only one-third of the corresponding values in the case of the L. 1929 populations (cp. Table 3).

As in the case of all other populations a fairly high degree of correlation occurs between food and growth, since from Table 16,

$$
\begin{aligned}
\mathrm{p} & =\frac{322}{62}-(\cdot 629 \times \cdot 742) \\
& =4.727
\end{aligned}
$$

and

$$
\mathrm{r}=\frac{\mathrm{p}}{\sigma_{\mathrm{x}} \sigma_{\mathrm{y}}}=\frac{4 \cdot 727}{2 \cdot 57 \times 2.93}=\cdot 6276(\cdot 63 \pm \cdot 08) .
$$

The correlation coefficient is smaller, however, than those of the L. 1929 populations, which are $\cdot 78(\widehat{\delta})$ and $\cdot 70$ (ㅇ) respectively (Table 4 ).

The regression coefficients of $x$ on $y$, i.e. $b_{x}$, of the $L$. 1929 populations were seen to be distinctly uniform, the differences between the sexes being negligible (Table 4). The corresponding coefficient of the L.W. populations provides a striking contrast, for

$$
\mathrm{b}_{\mathrm{x}}=\frac{\cdot 628 \times 2.57}{2.93 \times 5}=\cdot 110( \pm \cdot 017)
$$

Change in $\mathrm{x}$ corresponding to unit change in $\mathrm{y}$ is thus, on the average, greater during the winter months than during the summer months, in the ratio of $110: 87$, i.e. growth efficiency is enhanced even though growth is restricted. (Note : Strictly, this relates to the onset of a new growth season, that of 1930, since the individuals showing growth are those which have passed through the winter period of growth inhibition. In this connection it is interesting to observe that the L.W. regression coefficient $b_{x}$ agrees very closely with the corresponding coefficients of the L. 1930 groups.)

By substitution of mean values $(\bar{x}$ and $\bar{y})$ in the regression equation, the following equation is obtained :

$$
\mathrm{x}=\cdot 110 \mathrm{y}-1 \cdot 43
$$

By making $\mathrm{x}=0$, it is found that $\mathrm{y}=13$, so that, on the average, maintenance demands are reduced during the winter months in the ratio of $13 / 16-25$. If small weight increases are permitted, the reduction is more strongly marked, for when $\mathrm{x}=5, \mathrm{y}=17$, so that the ratio becomes $17 / 28-36$. 
Corresponding contrast is seen in the case of the regression of $y$ on $x$, for the regression coefficient

$$
\mathrm{b}_{\mathrm{y}}=\frac{\cdot 628 \times 2.93 \times 5}{2.57}=3.576(3 \cdot 6 \pm \cdot 6)
$$

(cp. Table 4, L. 1929). After substitution of means, the regression equation becomes

$$
\mathrm{y}=3 \cdot 58 \mathrm{x}+20 \cdot 8 \text {. }
$$

Thus the regression line of $\mathrm{y}$ on $\mathrm{x}$ is shifted nearer to the y zero co-ordinate, that of $\mathrm{x}$ on $\mathrm{y}$ being shifted nearer to the $\mathrm{x}$ zero co-ordinate, during the winter months. Moreover, both regression lines are considerably less steep than during the previous summer.

\section{Notation Used.}

$\overline{\mathrm{X}}$ Mean weight.

$\sigma_{\mathrm{x}}$ Standard deviation of weight.

$\bar{x}$ Mean growth in weight.

$\sigma_{\mathrm{x}} \quad$ Standard deviation of growth.

$\bar{y}$ Mean percentage of initial body-weight as food.

$D_{x}$ Difference between arbitrary and true weight means.

$D_{y}$ Difference between arbitrary and true percentage means.

f Frequency.

$\mathrm{n}$ Total number of frequencies.

$\Sigma$ Summation.

r Correlation coefficient.

$b_{x}$ Regression coefficient of $\mathrm{x}$ on $\mathrm{y}$.

$b_{y}$ Regression coefficient of $y$ on $x$.

$\mathrm{x})$

y

Any value of the variates within ranges stated.

$\mathrm{p}$ Product of deviations from means.

$\sigma_{\mathrm{mx}}$ Standard deviations of means of $\mathrm{x}$ arrays.

$\sigma_{\mathrm{my}}$ Standard deviations of means of y arrays.

$\eta_{\mathrm{xy}}$ Correlation ratio of $\mathrm{x}$ on $\mathrm{y}$.

$\eta_{\mathrm{yx}}$ Correlation ratio of $\mathrm{y}$ on $\mathrm{x}$.

$\eta^{2}-\mathrm{r}^{2}$ A measure of the divergence of the actual line through the means of arrays from line of regression.

\section{SUMMARY.}

The aim of the paper has been to treat the data of the Plaice experiments on Growth and Maintenance, carried out at Cawsand and Lympstone during 1929 and 1930, in a statistical manner. The experiments for each sex, year and place have been resolved into experiments with an 
average plaice during the "average" 14 days of the third growth season. Growth and food-percentage indices have been provided and a fairly high degree of correlation between food and growth has been indicated, and shown to be uniform for the sexes. Regression coefficients indicating the facility with which food is utilised for purposes of growth have been worked out and have been shown to vary with place and year, but not with sex. Maintenance demands have been evaluated and shown to be slightly greater in males than in females. The diminished demands during winter months have also been evaluated. The outstanding features of the results are the distinct differences shown between the Cawsand and Lympstone plaice, which differences it is suggested arise out of size differences to a large extent.

\section{REFERENCES.}

1. Dawes, Ben. 1930. Growth and Maintenance in the Plaice (Pleuronectes platessa L.). Part I. Journ. Mar. Biol. Assoc., N.S., Vol. XVII, No. 1.

2. Dawes, Ben. 1931. Ditto. Part II. Idem. Vol. XVII, No. 3.

3. Ford, E. 1928. Herring Investigations at Plymouth. I. Methods of Collection and Treatment of Data. Journ. Mar. Biol. Assoc., N.S., Vol. XV, No. 1.

4. Yule, G. A. 1924. An Introduction to the Theory of Statistics. London, Charles Griffin \& Co., Ltd. 
TABLE 8.

Correlation Table of Percentage of Body-Wt. as food and Wt. Increase. Cawsand Males [1929].

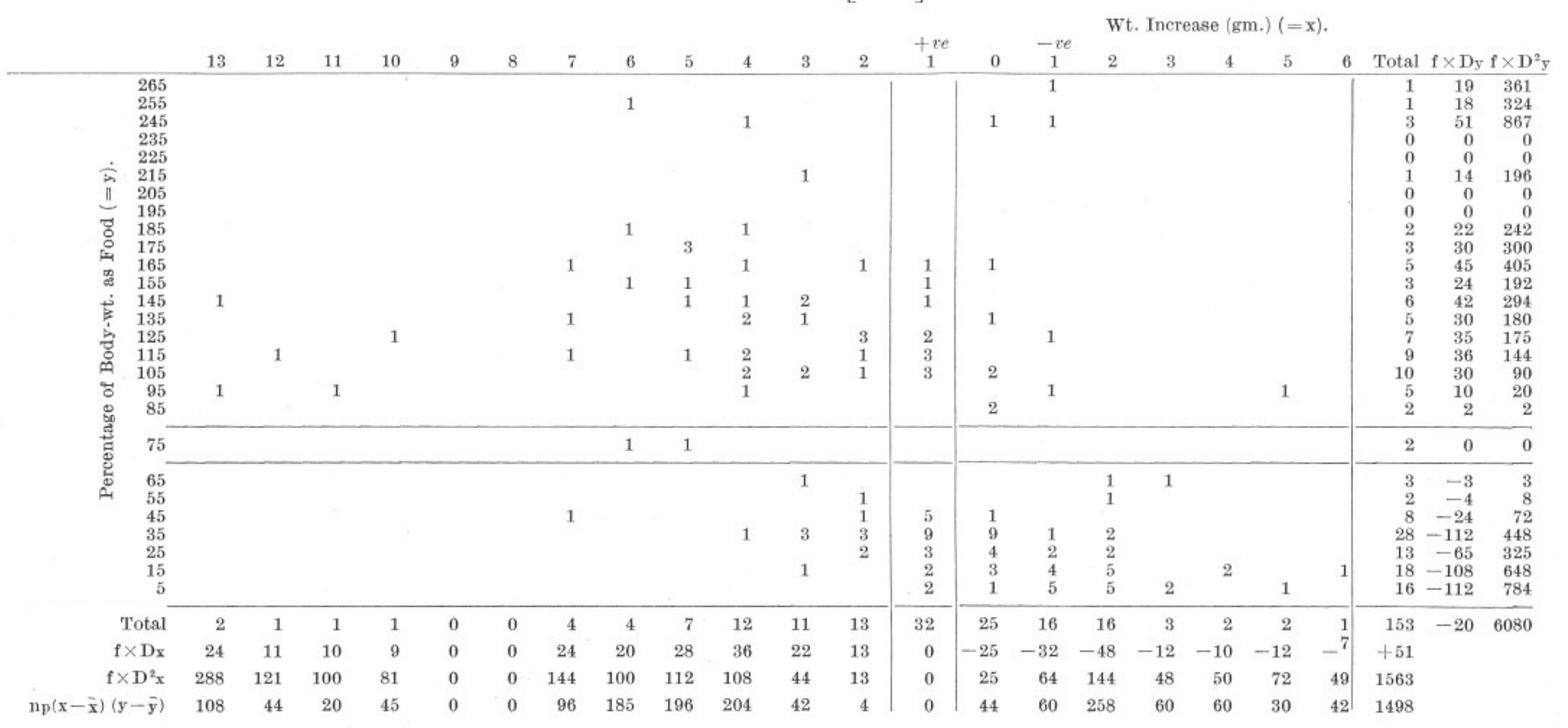


TABLE 9.

Correlation Table of Percentage of Body-Wt. as Food and Wt. Increase. Cawsand Females [1929].

Wt. Increase (gm.) $(=\mathrm{x})$.

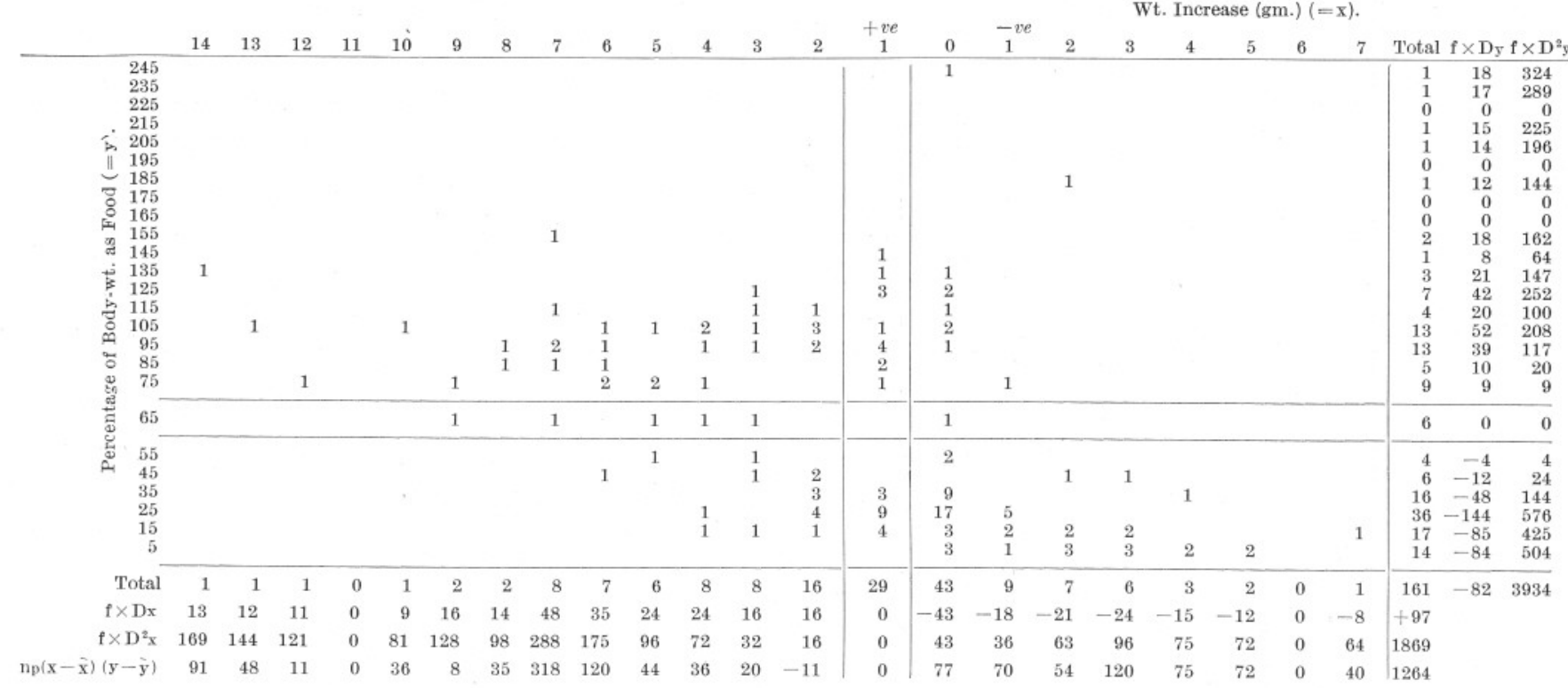


TABLE 10.

Correlation Table of Percentage of Body-Wt. as Food and Wt. Increase. Cawsand Males [1930].

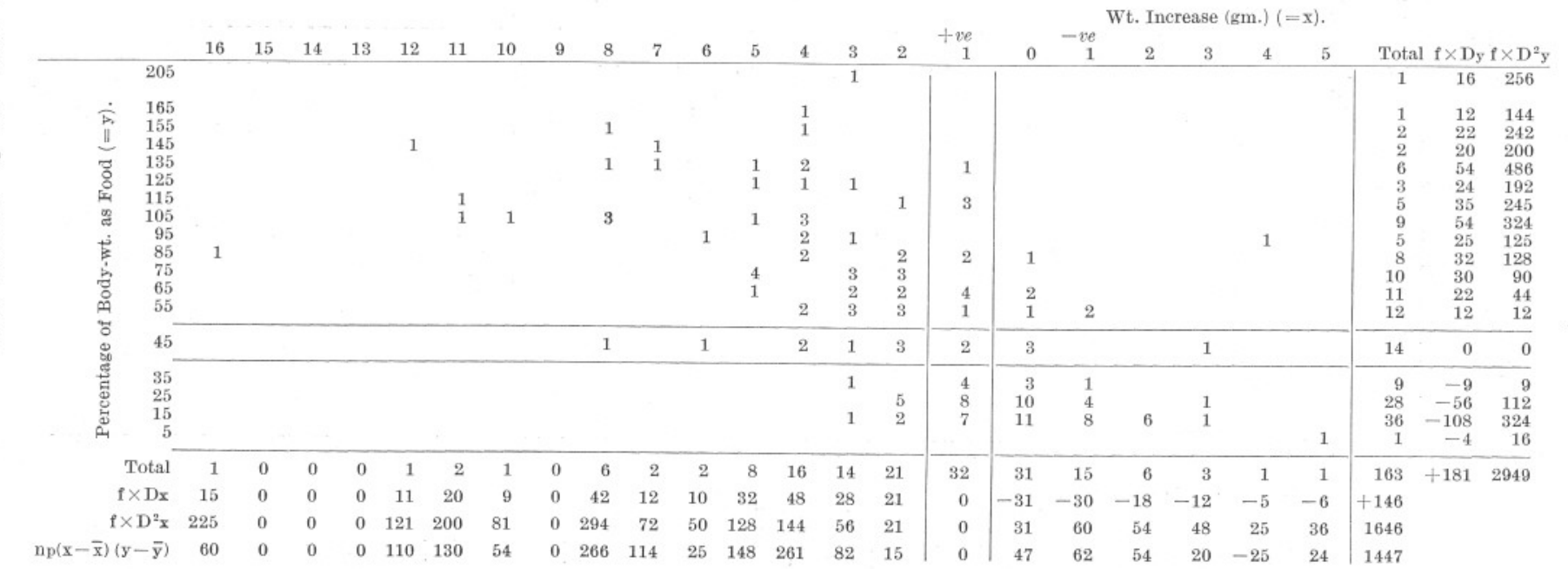


TABLE 11.

Correlation Table of Percentage of Body-Wt. as Food and Wt. Increase. Cawsand Females [1930].

Wt. Increase (gm.) $(=\mathrm{x})$

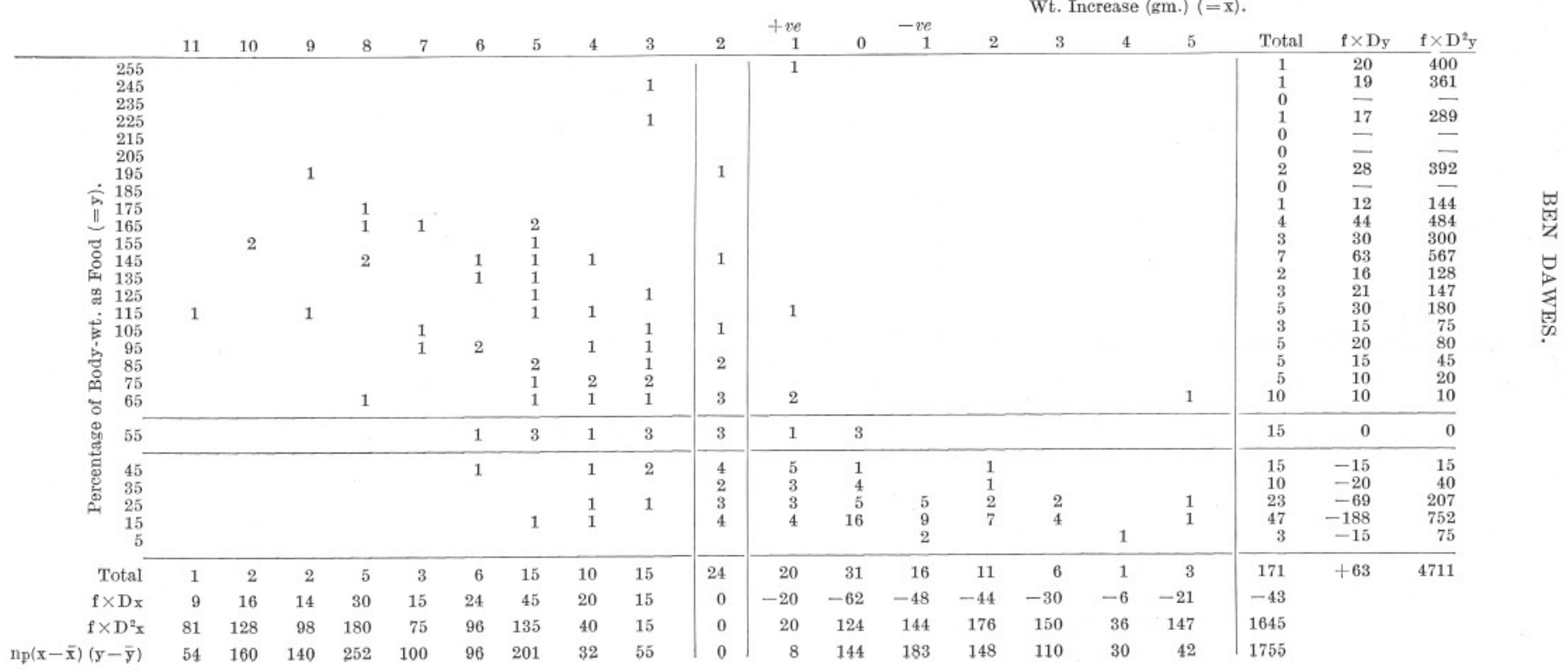




\section{TABLE 12.}

Correlation Table of Percentage of Body-Wt. as Food and Wt. Increase.

Lympstone MaLes [1929].

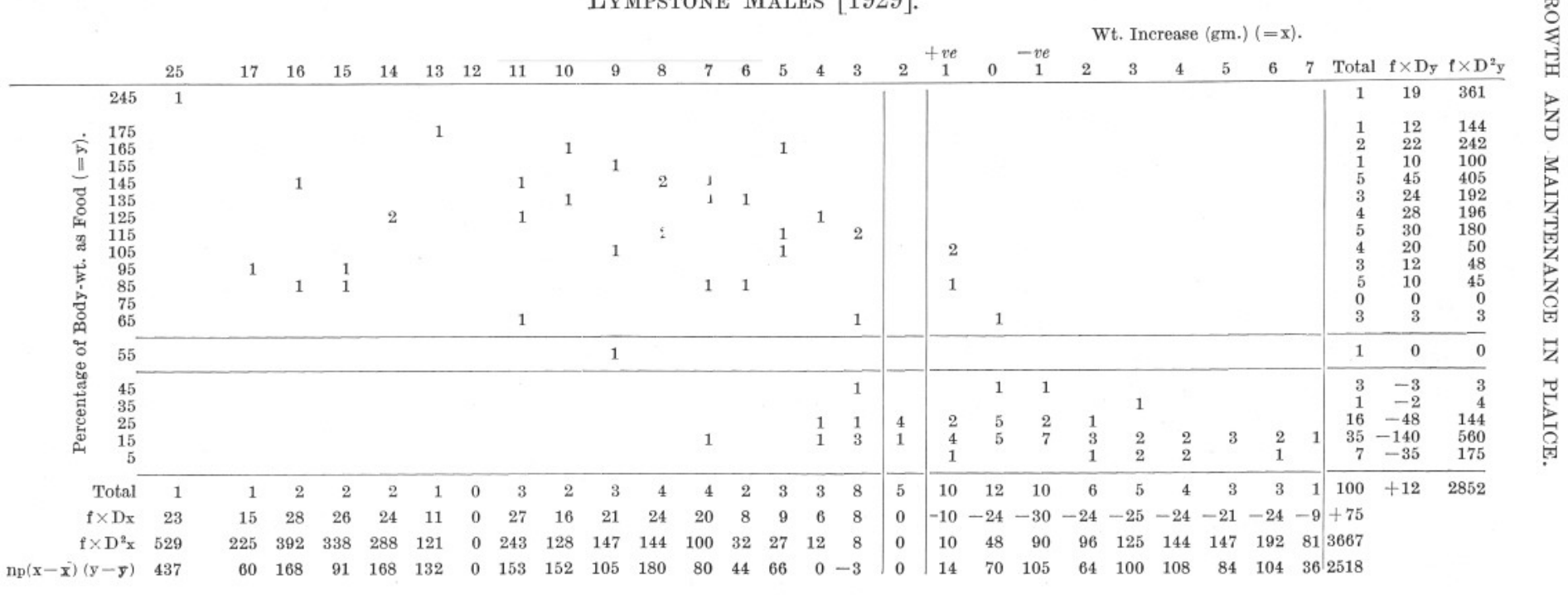


TABLE 13.

Correlation Table of Percentage of Body-Wt. as Food and Wt. Increase. Lympstone Females [1929].

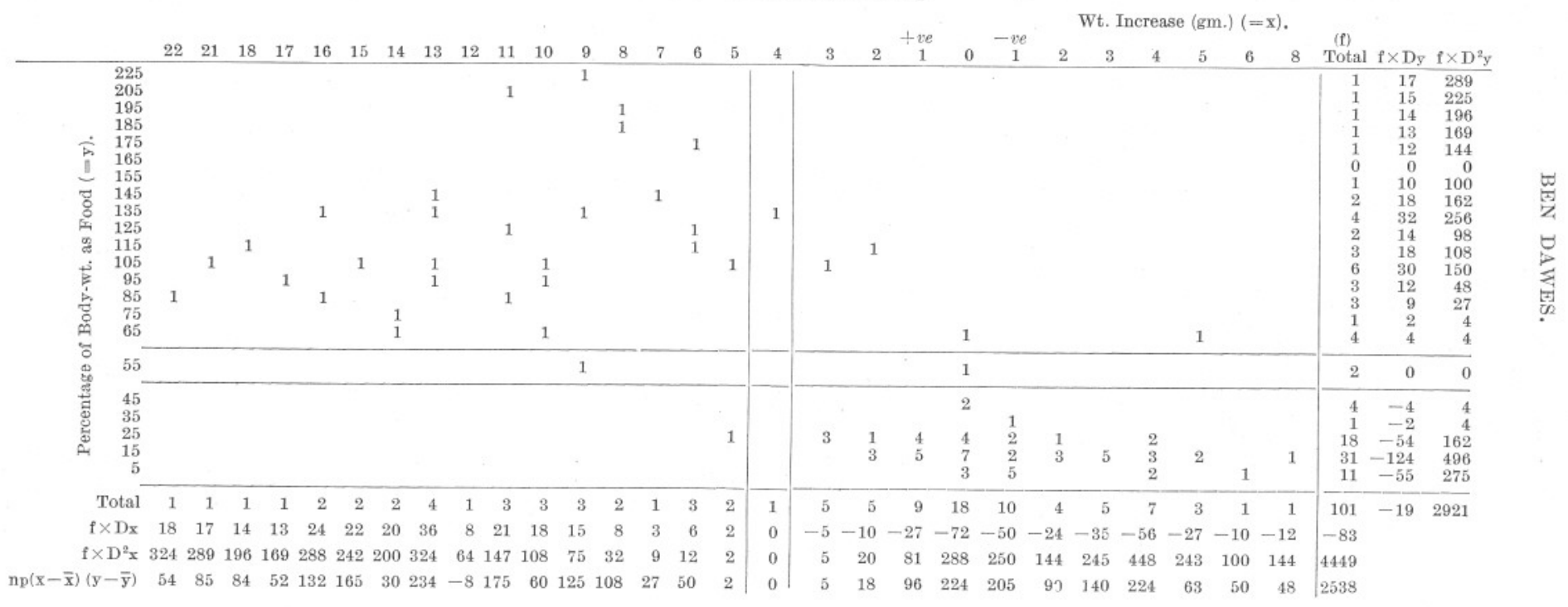


TABLE 14.

Correlation Table of Percentage of Body-Wt. as Food and Wt. Increase. Lympstone Males [1930].

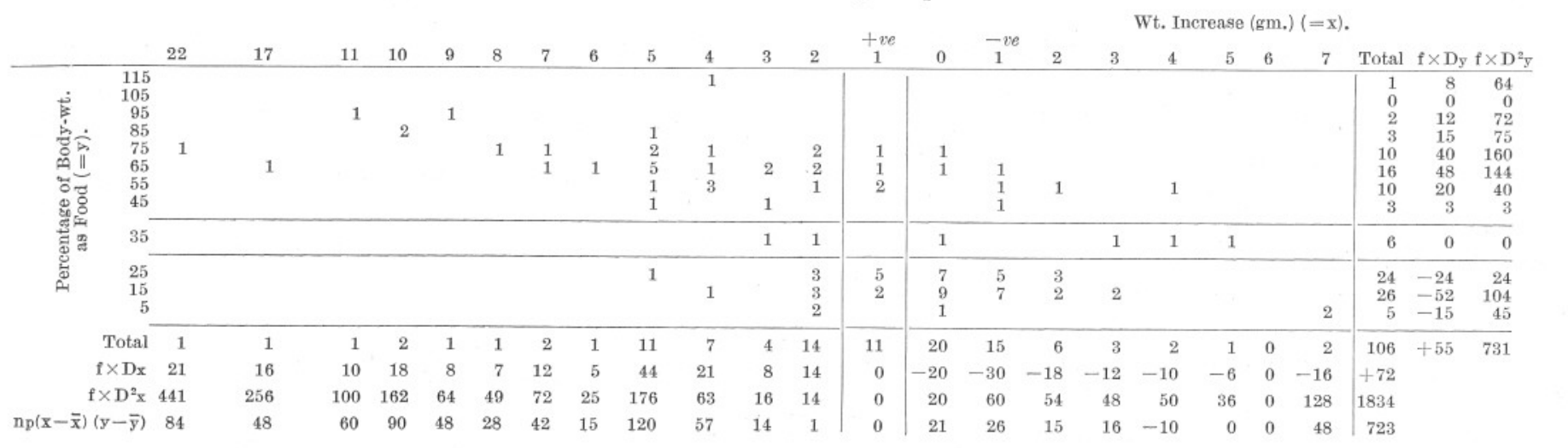


TABLE. 15.

Correlation Table of Percentage of Body-Wt. as Food and Wt. Increase.

Lympstone Females [1930].

Wt. Increase (gm.) $(=\mathbf{x})$.

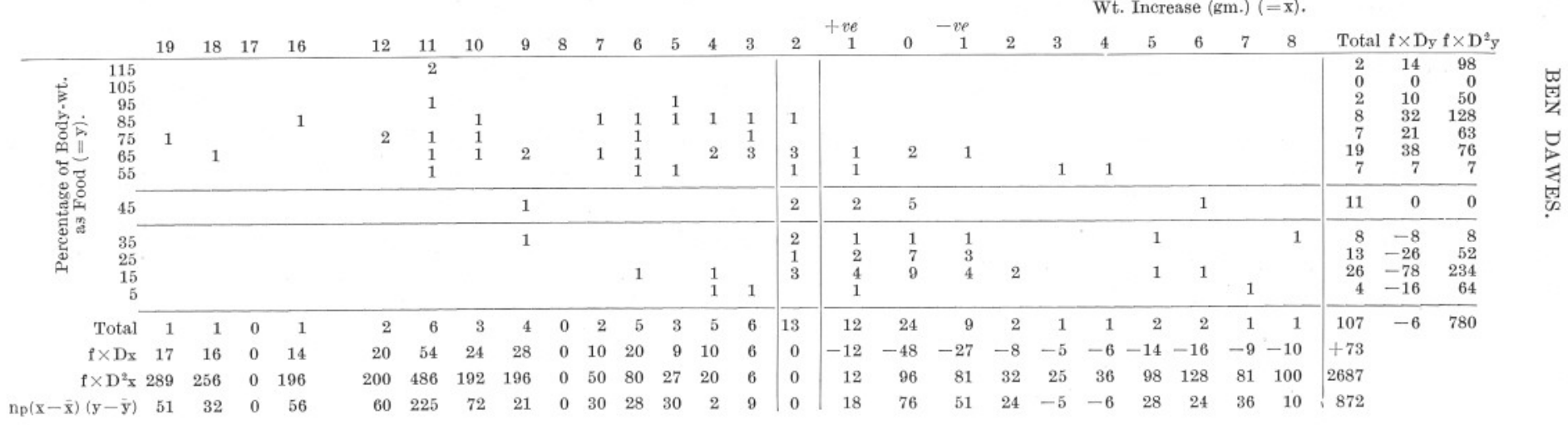


TABLE 16.

Correlation Table of Percentage of Body-Wt. as Food and Wt. Increase. LyMpstone Winter ô AND 우 [1930].

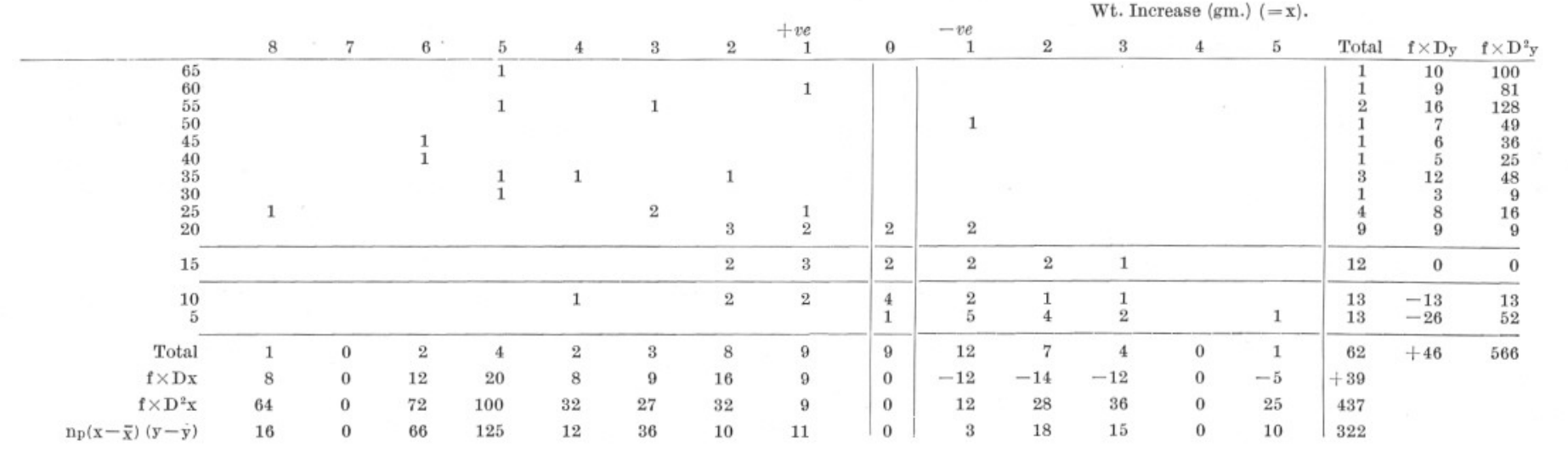


